\title{
SYTUACJA ŻYCIOWA OSÓB NIEPEŁNOSPRAWNYCH MIESZKAJĄCYCH W Polsce I CZYNNiki Ją Determinujące
}

\author{
Marta PAPIERniK \\ martadabek@o2.pl
}

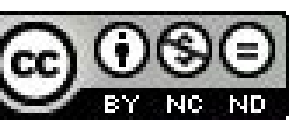

\section{WSTĘP}

W krajach Unii Europejskiej brak jednolitej definicji niepełnosprawności . Efektem dążenia do ujednolicenia i uporządkowania określeń związanych z niepełnosprawnością było przyjęcie przez Światową Organizację Zdrowia (1980 r.) Międzynarodowej Klasyfikacji Uszkodzeń, Niepełnosprawności i Upośledzeń, w której wyodrębniono:

- uszkodzenie (impairment) - „wszelka strata lub wada psychiczna, fizjologiczna, lub anatomiczna struktury lub czynności"2;

- niepełnosprawność (disability) - stan będący konsekwencją uszkodzenia objawiający się zmniejszeniem bądź brakiem zdolności wykonywania czynności w sposób uważany za normalny dla człowieka i w zakresie właściwym osobom pełnosprawnym;

- upośledzenie (handicap) - „niekorzystna (gorsza) sytuacja danej osoby, będąca wynikiem uszkodzenia lub niepełnosprawności, polegająca na ograniczeniu lub uniemożliwieniu jej wypełniania ról, które uważane są za normalne biorąc pod uwagę jej wiek, płeć, czynniki kulturowe i społeczne" ${ }^{\prime \prime 3}$.

Omawiana wyżej klasyfikacja WHO spotkała się z krytyką z powodu zbyt dużej koncentracji na aspekcie biomedycznym. Efektem tego niezadowolenia był społeczny model niepełnosprawności ${ }^{4}$ powstały w Wielkiej Brytanii, Stanach Zjednoczonych i krajach skandynawskich. Zakładał on, iż na przyczynę niepełnosprawności składa się brak odpowiednich usług oraz służb, które by właściwie zaspokajały potrzeby osób dotkniętych niepełnosprawnością. Społeczny model niepełnosprawności odpowiedzialnością za pokonanie barier architektonicznych, społecznych, ekonomicznych oraz prawnych obarczał całe społeczeństwo.

Obecnie za wzorzec ujmowania problematyki niepełnosprawności uważa się zatwierdzoną w 2001 r. przez WHO Międzynarodową Klasyfikację Funkcjonowania, Niepełnosprawności i Zdrowia (International Classification of Functioning Disability and Health). Według której „człowiek jest istotą biologiczną (...). Jest również określoną osobą działającą i wypełniającą określone zadania oraz członkiem określonej grupy społecznej, do której przynależy i w życiu której uczestniczy"7. W świetle nowego podziału pojęcie „niepełnosprawności” zostało zastąpione „ograniczeniem sprawności”, zaś „upośledzenie” „ograniczeniem uczestnictwa”"

W Polsce za osobę niepełnosprawną uznaje się osobę, której sprawność fizyczna, psychiczna lub umysłowa utrudnia trwale lub okresowo, ogranicza bądź uniemożliwia życie codzienne, naukę, pracę oraz pełnienie ról społecznych ${ }^{9}$.

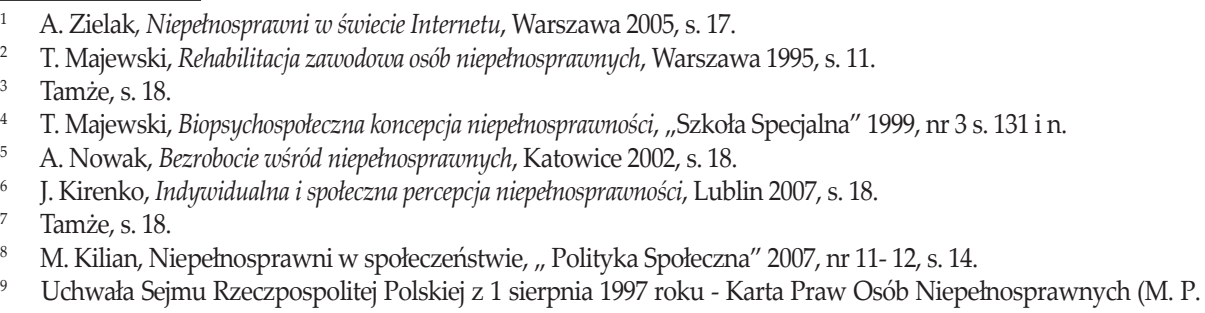


Ewolucja pojęcia niepełnosprawności obrazuje zmiany, jakie zaszły w postrzeganiu osób niepełnosprawnych przez „sprawną” część społeczeństwa. Zmiany te są podstawowym i koniecznym warunkiem integracji społecznej.

Mając na uwadze przemiany jakie dokonały się w postrzeganiu niepełnosprawności na przestrzeni wieków Dykcik wyróżnił następujące modele:

- model moralny - niepełnosprawność była odbierana jako skutek zła i grzechu, natomiast sami niepełnosprawni postrzegani byli jako słabi, niedołężni, oszpeceni, uciążliwi i niesamodzielni, a przy tym niemoralni, o zachowaniach społecznych odbiegających od normy. Dominowała postawa wrogości, niechęci wobec tej grupy, mająca swoje korzenie w bezwzględnym prawie selekcji naturalnej. Poglądy takie przeważały w starożytności i utrzymywały się aż do wczesnego średniowiecza, kiedy to niepełnosprawni byli eliminowani jako osoby uciążliwe i bezużyteczne dla społeczeństwa, bądź pozwalano na ich zmarginalizowaną obecność, przy czym ich status społeczny był bardzo niski, zasiedlali oni grono żebraków lub włóczęó́w ${ }^{10}$. Tak negatywne postrzeganie tej grupy wynikało w głównej mierze z nieuświadomienia sobie możliwości ich aktywnego życia i funkcjonowania w społeczeństwie.

- model charytatywnej opieki i filantropijnej pomocy - ideały humanizmu, w tym chrześcijańskiego, przyczyniły się do stopniowej zmiany stosunku wobec osób niepełnosprawnych. Był to okres, w którym dominowała litość, miłosierdzie, ale zarazem strach przed osobami odbiegającymi od normy. Jednostki takie były w większości izolowane od społeczeństwa w przytułkach, bądź innych placówkach opieki. Stworzono także specjalne schroniska dla dzieci ociemniałych, głuchych i kalekich. Mimo podjęcia, w tym okresie, próby systematycznego kształcenia osób niepełnoprawnych nadal przeważała opinia, że możliwość ich adaptacji społecznej jest znacznie ograniczona.

- model medyczny - miał on swoje źródło w filozofii oświecenia na początku XVIII w. Osoby niepełnosprawne były w nim z założenia traktowane jako odpychające, niezdolne do samodzielnego życia, a wręcz uciążliwe i niechciane. Efektem tego podejścia było wykluczenie ich ze społeczeństwa i oddanie pod ścisłą opiekę lekarza. Charakterystyczne było traktowanie tej grupy ludzi jako przypadki medyczne. Wychodzono z założenia, że wszelkie przeżywane przez nich problemy są jedynie konsekwencjami choroby lub uszkodzenia organizmu.

- model społeczny - wiąże się on z postrzeganiem osób niepełnosprawnych jako dyskryminowaną mniejszość, której przysługują pewne prawa. Nadrzędnym celem jest stopniowa zmiana postaw społeczeństwa oraz włączanie tej grupy do możliwie najpełniejszego uczestniczenia we wszystkich dziedzinach życia ${ }^{11}$. Podejście to akcentuje "zewnętrzne" przyczyny niepełnosprawności. Upatruje się ich w różnego rodzaju ograniczeniach środowiska wypływających z licznych barier społecznych, fizycznych oraz ekonomicznych.

W większości państw cywilizacji zachodniej aż do XX wieku osoby niepełnosprawne były poniżane i wykluczane z aktywnego życia w społeczeństwie. Dopiero w XX wieku nastąpił przełom w myśleniu o niepełnosprawności. Duże zasługi w przełamywaniu stereotypów dotyczących ludzi niepełnosprawnych miała Wielka Brytania. To właśnie tam w latach osiemdziesiątych ubiegłego stulecia doszło do znaczącej transformacji w rozumieniu niepełnosprawności ${ }^{12}$.

10 M. Mazur, Ja też mogę pomagać - o potrzebie budowania wolontariatu wśród osób niepełnosprawnych, [w:] J. Śliwak (red.), Psychospołeczne problemy zatrudnienia osób niepetnosprawnych, Lublin 2007, s. 128.

11 W. Dykcik, Filozoficzna koncepcja osoby ludzkiej i wartościowania życia niepetnosprawnego człowieka, szansą twórczego rozwoju pedagogiki specjalnej, [w:] Z. Gajdzica, A Klinik (red.), Wattki zaniedbane, zaniechane, nieobecne w procesie edukacji i wsparcia społecznego osób niepełnosprawnych, Katowice 2004, s. 29-30.

12 http://www.rnid.org.uk, 20.11.2010. 
Między innymi za sprawą Deklaracji Równych Praw Człowieka i Obywatela (1975 r.) osoby z ograniczoną sprawnością zyskały możliwość pełniejszej integracji społecznej i zawodowej. Zmiana ta pociągnęła za sobą powstanie wielu organizacji pracujących na rzecz osób z niepełnosprawnościa, $\mathrm{w}$ tym także stowarzyszeń samych niepełnosprawnych. Pełnosprawna część społeczeństwa zyskała możliwość obserwacji, z jaką pasją i determinacją potrafią pracować ludzie niepełnosprawni, do tej pory uważani za biernych i niesamodzielnych. Powstała też nowa koncepcja pomocy polegająca na tym, że osoby z niepełnosprawnością zaczęto traktować jak zwykłych obywateli i zamiast przyznawać im kolejne przywileje dokładano starań, aby wyrównać ich szanse. Takie myślenie znalazło swoje odzwierciedlenie $\mathrm{w}$ podstawowych regulacjach prawa międzynarodowego poświęconych tematyce niepełnosprawności.

Na poprawę sytuacji życiowej osób niepełnosprawnych miały również wpływ naukowe zainteresowania niepełnosprawnością. Pod koniec ubiegłego stulecia $\mathrm{w}$ ramach studiów nad niepełnosprawnością (Disability Studies) podejmowanych przez socjologów, pedagogów, psychologów, politologów i wielu innych przedstawicieli nauki powstała holistyczna koncepcja niepełnosprawności. Koncepcja ta wskazywała na potrzebę większego udziału osób niepełnosprawnych w życiu społecznym i otwarcia się „,sprawnej” części społeczeństwa na współpracę z osobami niepełnosprawnymi.

Wzrostowi wiedzy o niepełnosprawności towarzyszył wzrost świadomości i wrażliwości społecznej w odniesieniu do sytuacji życiowej osób niepełnosprawnych.

Polskie prawo na mocy ustawy z dn. 7. września 1991 r. o systemie oświaty (Dz. U. z 2004 r. Nr 256, poz. 2572 z późn. zm.) „(..) gwarantuje każdemu uczniowi warunki niezbędne do rozwoju:

- możliwość pobierania nauki we wszystkich typach szkół przez dzieci i młodzież niepełnosprawną oraz niedostosowaną społecznie, zgodnie z indywidualnymi potrzebami rozwojowymi i edukacyjnymi oraz predyspozycjami;

- dostosowanie treści, metod i organizacji nauczania do możliwości psychofizycznych uczniów, a także możliwość korzystania z pomocy psychologiczno- pedagogicznej i specjalnych form pracy dydaktycznej;

- opiekę nad uczniami niepełnosprawnymi przez umożliwianie realizowania zindywidualizowanego procesu kształcenia, form i programów nauczania oraz zajęć rewalidacyjnych" ${ }^{\prime 13}$.

Dorosłe osoby niepełnosprawne mają możliwość podjęcia pracy u boku osób zdrowych ${ }^{14}$. We współczesnym procesie integracyjnym zatrudnienie osób z niepełnosprawnościa, zwłaszcza na otwartym rynku pracy ma ogromne znaczenie. Praca stanowi istotną wartość w życiu każdego człowieka. W życiu osoby niepełnosprawnej praca odgrywa szczególną rolę - daje poczucie sensu, bycia potrzebnym, poczucie sprawstwa. Jest więc najlepszą drogą do rehabilitacji ${ }^{15}$.

Kolejnym ważnym elementem mającym wpływ na sytuację życiową niepełnosprawnych są media. Za ich pośrednictwem możliwe jest stopniowe oddziaływanie na społeczeństwo, walka ze stereotypami i uprzedzeniami. Rozpowszechniane hasła "Niepełnosprawni - pełnosprawni w pracy", czy "Nie chcę niczego za darmo" mają na celu zmianę negatywnego wizerunku ludzi niepełnosprawnych z biernych i roszczeniowych na aktywnych zawodowo i otwartych .

13 www.legeo.pl/prawo/dziennik-ustaw-2004/256/2572, 19.11.2010.

14 J. Campbell, M. Oliver, Disability Politics, London 1996, s. 18.

Por. M. Paszkowicz, Wybrane aspekty funkcjonowania osób z niepełnosprawnościami, Zielona Góra 2009; J Kirenko, Indywidualna i społeczna percepcja niepetnosprawności, Lublin 2007; H. Ochonczenko, M. Paszkowicz (red.) Potrzeby osób niepetnosprawnych w warunkach globalnych przemian społeczno- gospodarczych, Kraków 2006; A Jasiak, D. Swereda, Ergonomia osób niepełnosprawnych, Poznań 2009; A. Nowak, Wybrane edukacyjne i prawne aspekty niepełnosprazności, Kraków 1999. 
Pomimo znaczącej poprawy sytuacji osób niepełnosprawnych nadal są one narażone na trudności niemal we wszystkich sferach życia. Zaczynając od barier fizjograficznych - bezpośrednio powiązanych z naturalnym otoczeniem człowieka (ich przykładem może być ukształtowanie terenu czy niesprzyjające warunki atmosferyczne), po bariery techniczne, w skład których wchodzą:

- bariery urbanistyczne - uwarunkowane m.in. sygnalizacją świetlną na przejściach dla pieszych, miejscami parkingowymi, komunikacja, są one związane z zabudową miast,

- bariery architektoniczne - zależne od architektury budynków zamieszkałych przez osoby niepełnosprawne oraz budynków gdzie te osoby funkcjonują (praca, urzędy, ośrodki rehabilitacji, sklepy itd.); o ich dostosowaniu bądźjego braku decydują między innymi schody, urządzenia sanitarne, drzwi itp.),

- bariery funkcjonalne - będące konsekwencją montażu i działania przedmiotów uwzględniających wyłącznie osoby sprawne,

- bariery komunikacyjne - obecne w środkach komunikacji publicznej, chodzi tu m.in. o niedostosowanie autobusów, pociagów, dworców do potrzeb osób niepełnosprawnych,

- bariery wzornicze, których przykładem mogą być ostre krawędzie, małe monitory komputerów, wyświetlacze telefonów itp. ${ }^{16}$.

Poprzez bariery o charakterze społecznym, w skład których wchodzą przeszkody:

- psychologiczne, chodzi tu o trudność osoby niepełnosprawnej w zaakceptowaniu własnej sytuacji będącej rezultatem niepełnej sprawności. Może ona skutkować brakiem wiary w poprawę swojej sytuacji bądź nieufnością wobec innych osób. W skrajnych przypadkach mogą one prowadzić do załamania, braku nadziei, stanu apatii ${ }^{17}$,

- mentalne, obejmujące negatywne reakcje oraz postawy osób zdrowych wobec ludzi niepełnosprawnych, przejawiające się niechęcia, wrogościa, dyskryminacją czy obojętnością na problemy. Do barier mentalnych wliczamy także uprzedzenia i stereotypy wobec niepełnosprawnych, prowadzące do ich marginalizacji i izolacji społecznej ${ }^{18}$,

- prawne, ich wyrazem może byćnegatywny stosunek wobec jakiejś grupy ludzi utrwalony w formie przepisów prawnych. Omawiane bariery mogą opóźniać proces rehabilitacji oraz integracji społecznej poprzez szereg ograniczeń (nakazów lub zakazów) sankcjonowanych prawnie ${ }^{19}$,

- ekonomiczne, najczęściej spotykane spośród barier społecznych, wynikające z niskich dochodów oraz wysokich kosztów leczenia, rehabilitacji, leków itp., stanowią one dotkliwą i dużą przeszkodę na drodze do integracji i podwyższania jakości życia osób niepełnosprawnych ${ }^{20}$.

Dodatkowo niepełnosprawni są postawieni przed niełatwym zadaniem sprostania wymogom współczesności. Od „dzisiejszego" pracownika oczekuje się dużej elastyczności, operatywności, mobilności, znakomitego odnajdowania się $\mathrm{w}$ nowych sytuacjach, łatwego nawiązywania kontaktów. Media propagują pewien ideał współczesnego człowieka kładąc nacisk na piękno zewnętrzne, zdrowie czy sprawność fizyczną. Osobom niepełnosprawnym bardzo trudno sprostać tym wymaganiom. Za sprawą ograniczonego uczestnictwa w życiu społecznym osoby

${ }_{16}$ J. Zarzeczny, Sytuacja niepetnosprawnych w Polsce i w Unii Europejskiej, [w:] A. Kubów, M. Wawrzak-Chodaczek, J. Wojtaś, J. Zarzeczny, Badanie mobilności edukacyjno zawodowej osób niepetnosprawnych w wojezwództwie dolnoślaskim, Legnica 2008, s. 9 .

17 C. Barnes, Disabling of Disabled People, Halifax 1992, [cyt. za:] A. Kubów, M. Wawrzak-Chodaczek, J. Wojtaś, J. Zarzeczny, Badanie mobilności edukacyjno-zawodowej osób niepetnosprawnych w województwie dolnoślaskim, Legnica 2008, s. 9.

18 A. Kubów, M. Wawrzak-Chodaczek, J. Wojtaś, J. Zarzeczny, Badanie mobilności..., dz. cyt., s. 9.

19 Tamże, s. 9-10.

20 Tamże, s. 10. 
niepełnosprawne są grupą szczególnie narażoną na marginalizację i defaworyzowanie. Kowalik podaje pięć praktyk dyskryminacyjnych jakich doświadczają osoby niepełnosprawne ${ }^{21}$. Dystansowanie się polega na unikaniu bliskich i nieformalnych kontaktów z osobami niepełnosprawnymi, kontakt z nimi (jeśli jest) nie wykracza poza konieczne obowiązki służbowe. Charakterystyczne dla tej praktyki są: brak zainteresowania wobec problemów emocjonalnych osób niepełnosprawnych i wzbranianie się przed udzieleniem im pomocy. Kolejną z praktyk dyskryminacyjnych jest dewaluowanie, polega na przypisywaniu niepełnosprawnym negatywnych cech i rozpowszechnianiu tych poglądów, przez co pośrednio wpływa się na odbiór niepełnosprawnych przez społeczeństwo. Praktyka ta może skutkować trudnościami osób niepełnosprawnych w znalezieniu zatrudnienia, z budowaniem poczucia własnej wartości itp.

Z delegitymizacją mamy do czynienia wówczas, gdy „negatywny, psychologiczny stosunek jednych ludzi wobec drugich zostaje utrwalony społecznie w postaci odpowiednich przepisów prawnych"22. Przykładem może być umieszczanie dzieci upośledzonych umysłowo wyłącznie w specjalnych placówkach i ośrodkach.

Z kolei segregacja przejawia się $\mathrm{w}$ fizycznym izolowaniu jednostki lub całej grupy od otoczenia. Zazwyczaj oznacza to gorsze warunki życia i funkcjonowania. Segregacja może mieć charakter kilkugodzinny (segregacja poprzez umieszczenie w placówce specjalnej) bądź całkowity (całodobowy pobyt $\mathrm{w}$ ośrodku).

Najbardziej drastyczną i skrajną praktyką dyskryminacyjną jest eksterminacja, polegająca na biologicznym wyniszczaniu ludzi, którzy zaliczają się do danej kategorii społecznej. Współcześnie tak radykalne formy dyskryminacji oficjalnie nie występują.

\section{Podsumowanie}

Już samo prześledzenie ewolucji pojęcia „niepełnosprawność” obrazuje zmiany jakie dokonały się w sytuacji życiowej osób niepełnosprawnych. Różne sposoby definiowania niepełnosprawności wskazują na złożoność tego zjawiska i konieczność rozpatrywania go w wielu aspektach: przestrzeni, czasu, szerokości geograficznej, kontekstu społecznego i kulturowego.

Na sytuację życiową osób niepełnosprawnych wpływ mają m. in. poziom wiedzy na temat niepełnosprawności, polityka umożliwiająca niepełnosprawnym integrację z resztą społeczeństwa począwszy od przedszkola po pracę zawodowa, ale przede wszystkim nastawienie otoczenia do niepełnosprawnych. Pozytywnemu nastawieniu do osób niepełnosprawnych mogą sprzyjać: media i walka z przejawami dyskryminacji.

Osobyniepełnosprawnestanowiąwe współczesnym społeczeństwie „największąmniejszość", dlatego celem działań zmierzających do poprawy sytuacji osób niepełnosprawnych powinno być wielowymiarowe wyrównanie szans. Pomimo istnienia w Polsce przepisów sprzyjających integracji osób niepełnosprawnych w środowiskach szkolnych i zawodowych brak znajomości ustaw przez osoby niepełnosprawne uniemożliwia skuteczne egzekwowanie prawa. Potrzebni są radcy prawni i doradcy zawodowi specjalizujący się w pomocy osobom niepełnosprawnym. Warto również skorzystać z doświadczeń innych krajów takich jak Zjednoczone Królestwo czy Kanada, być może część ze stosowanych tam rozwiązań uda się zaadaptować na grunt polski.

Właściwe wykorzystanie dofinansowań unijnych oraz państwowych dla likwidacji barier architektonicznych i społecznych oraz większa świadomość władz w uwzględnianiu potrzeb i możliwości niepełnosprawnych może znacząco poprawić sytuację życiową tych osób.

${ }_{21}$ S. Kowalik, Psychospołeczne podstawy rehabilitacji osób niepetnosprawnych, Warszawa 1996, s. 162-163.

22 Tamże, s. 163. 
Warto także zachęcać osoby niepełnosprawne do podnoszenia kwalifikacji zawodowych, gdyż jest to konieczny warunek aby sprostać wymogom jakie stawia współczesny rynek pracy.

Pomimo, iż obecnie sytuacja osób z niepełnosprawnością nadal jest daleka od ideału, jest ona uwarunkowana wieloma czynnikami: politycznymi, gospodarczymi, ekonomicznymi, wreszcie społeczno- kulturowymi, dlatego głębokie zmiany wymagają czasu.

\section{Bibliografia}

Barnes C., Disabling of Disabled People, British Counsil of Organizations of Disabled People and Ryburn Publishing Limited, Halifax 1992.

Campbell J., Oliver M., Disability Politics, London 1996.

Dryżałowska G., Niepetnosprawność, [w:] Encyklopedia pedagogiczna XXI wieku, t. 3, Warszawa 2003.

Dykcik W., Pedagogika specjalna, Poznań 1998.

Dykcik W., Wprowadzenie w przedmiot pedagogiki specjalnej jako nauki, [w:] Dykcik W. (red.), Pedagogika specjalna, Poznań 2001.

Gajdzica Z., Klinik A. (red.), Wạtki zaniedbane, zaniechane, nieobecne w procesie edukacji i wsparcia społecznego osób niepetnosprawnych, Katowice 2004.

Hulek A. (red.), Edukacja osób niepetnosprawnych, Warszawa 1993.

Kilian M., Niepetnosprawni w społeczeństwie, „, Polityka Społeczna” 2007, nr 11- 12.

Kirenko J., Indywidualna i społeczna percepcja niepetnosprawności, Lublin 2007.

Kleszczewska-Pyra E., Edukacja osób niepełnosprawnych przez życie we wspólnocie, [w:] Hulek A. (red.), Edukacja osób niepetnosprawnych, Warszawa 1993.

Kowalik S., Psychospoteczne podstawy rehabilitacji osób niepełnosprawnych, Warszawa 1996.

Kubów A., Wawrzak- Chodaczek M., Wojtaś J., Zarzeczny J., Badanie mobilności edukacyjno zawodowej osób niepetnosprawnych w województwie dolnoślaskim, Legnica 2008.

Majewski T., Biopsychospołeczna koncepcja niepełnosprawności, „Szkoła Specjalna” 1999, nr 3.

Majewski T., Rehabilitacja zawodowa osób niepetnosprawnych, Warszawa 1995.

Mazur M., Ja też mogę pomagać - o potrzebie budowania wolontariatu wśród osób niepetnosprawnych, [w:] Śliwiak J. (red.), Psychospoteczne problemy zatrudnienia osób niepetnosprawnych, Lublin 2007.

Mihilewicz S., Niepetnosprawność obszarem społecznej stereotypizacji i uprzedzeń, [w:] Wielokulturowość - Międzykulturowosśc obszarami edukacyjnych odniesień, Szerląg A. (red.), Kraków 2005.

Nowa A., Syrek E., Społeczno-socjalne aspekty marginalizacji chorych i niepetnosprawnych w społeczeństwie ryzyka, [w:] K. Marzec-Holka, Marginalizacja w problematyce pedagogiki społecznej i praktyce pracy socjalnej, Bydgoszcz 2005.

Nowak A., Bezrobocie wśród niepetnosprawnych, Katowice 2002.

Ochoczenko H., Paszkowicz M. (red.), Potrzeby osób niepetnosprawnych w warunkach globalnych przemian społeczno-gospodarczych, Kraków 2006.

Paszkowicz M., Wybrane aspekty funkcjonowania osób z niepetnosprawnościami, Zielona Góra 2009.

Rysz-Kowalczyk B. (red.), Leksykon polityki społecznej, Warszawa 2002.

Uchwała Sejmu Rzeczpospolitej Polskiej z dn. 1. sierpnia 1997 r. - Karta Praw Osób Niepetnosprawnych (M. P. 1997 r., Nr 50, poz. 475).

Zasępa E., Czabała Cz., Starzomska M., Postawy wobec niepełnosprawności i osób niepetnosprawnych, ", Człowiek - Niepełnosprawność-Społeczeństwo" 2005, nr 1.

Zielak A., Niepetnosprawni w świecie Internetu, Warszawa 2005.

\section{Netografia}

http://www.rnid.org.uk, 20.11.2010.

www.legeo.pl/prawo/dziennik-ustaw-2004/256/2572, 19.11.2010.

\section{Słowa kluczowe}

niepełnosprawność, prawo pracy, modele niepełnosprawności, naukowe zainteresowanie niepełnosprawnościa, edukacja i zatrudnienie osób z niepełnosprawnościa, stereotypy i uprzedzenia, bariery, praktyki dyskryminacyjne, defaworyzacja 


\section{STRESZCZENIE}

W artykule omówiona jest sytuacja życiowa osób niepełnosprawnych żyjących w Polsce. Mnogość definicji niepełnosprawności obrazuje złożoność zjawiska i wielość spojrzeń na źródło i jego konsekwencje. Stopniowe zmiany jakie zachodzą w odbiorze osób z ograniczoną sprawnością przez otoczenie, ukazują różne modele postrzegania niepełnosprawności. Na sytuację osób niepełnosprawnych wpływ mają między innymi: prawo (regulujące kwestie ich edukacji i zatrudnienia), bariery jakich doświadczaja, postawy otoczenia, możliwości podjęcia pracy na otwartym rynku pracy. Ważnym czynnikiem tworzącym opinie na temat osób nie w pełni sprawnych są media. Mogą one podtrzymywać zakorzenione stereotypy bądź je zwalczać. Nie można jednak zapomnieć, że ponieważ na sytuację osób niepełnosprawnych wpływają czynniki: polityczne, ekonomiczne, gospodarcze, wreszcie społeczno-kulturowe, jej zmiana wymaga czasu, zrozumienia potrzeb osób z niepełnosprawnością oraz aktywności samych zainteresowanych.

\section{Life Situation of The disabled living in Poland AND its Determinants}

\section{Keywords}

Disability, labour law, models of disability, scientific interest in disability, education and employment of the disabled, stereotypes and prejudices, barriers, discrimination habits, marginalization

\section{Summary}

This article contains a description of the life situation of the disabled living in Poland. Multitude of definitions of the word "disability" proves complexity of this phenomenon and plurality of angles on its source and consequences. Gradual changes in environment's reception of the disabled present different models of perceiving disability. There are various factors having an influence on disabled people's situation, among others the law regulating conditions of their education and employment, barriers present in their lives, attitudes of people around them and their opportunities to pursue employment on the open job market. The media are a very powerful source of opinions about the disabled. They may sustain the deeply-rooted stereotypes or help to overcome them. However, one cannot forget that because political, economical, social and cultural factors affect the situation of the disabled simultaneously, its change requires time and understanding of disabled people's needs as well as the participation of the disabled themselves. 